\title{
Aortic valvular tophus: identification by X-ray diffraction of urate and calcium phosphates
}

\author{
JM GAWOSKI, ${ }^{*}$ K BALOGH, ${ }^{*}$ WJ LANDIS $\dagger$ \\ From the ${ }^{*}$ Department of Pathology, Harvard Medical School and New England Deaconess Hospital, \\ Boston, Massachusetts, and the †Laboratory for the Study of Skeletal Disorders and Rehabilitation, \\ Department of Orthopaedic Surgery, Harvard Medical School, and the Children's Hospital Medical Center, \\ Boston, Massachusetts
}

SUMMARY A typical gouty tophus with birefringent, dichroic, needle shaped crystals was found in a resected calcified aortic valve on routine histological examination. The patient, an elderly man, had a long history of gout. X-ray diffraction confirmed the presence of sodium acid urate monohydrate and identified hydroxyapatite and whitlockite in the accompanying dystrophic calcification of the aortic valves. Previous reports indicate that gouty tophi of the cardiac valves are rare: of the nine cases reported, eight occurred in the mitral valve.

Tophi in cardiac valves are a rare manifestation of gout and have been reported in an aortic valve only once, in 1872, without histological evidence.' We found an incidental tophus in an aortic specimen obtained at valvulectomy. We studied the putative deposits of urate histochemically and by polarised light, and we obtained confirmatory evidence of calcium urate by $\mathrm{X}$-ray diffraction. To our knowledge this is the first reported identification by crystallography of urate in a cardiac valve.

\section{Case report}

A 71 year old white man with a history of episodic congestive heart disease was admitted for cardiac catheterisation. For 20 years he had passed multiple renal stones; he recalled that on analysis these had been found to contain uric acid and calcium. About 10 years before admission gout had been diagnosed. He had also had an episode of cerebral vascular insufficiency 13 years earlier and of uncomplicated myocardial infarctions six and nine years earlier, and he had a two to three year history of angina pectoris, cervical arthritis, hypertension, and hypercholesterolaemia. Physical examination and echocardiography suggested that he had myocardial hypertrophy and aortic regurgitation. Electrocardiography showed normal sinus rhythm with first degree

Accepted for publication 1 May 1985 atrioventricular block, intraventricular conduction delay, left ventricular hypertrophy, and probably old inferior and anterior infarcts. Cardiac catheterisation showed moderate aortic regurgitation with four

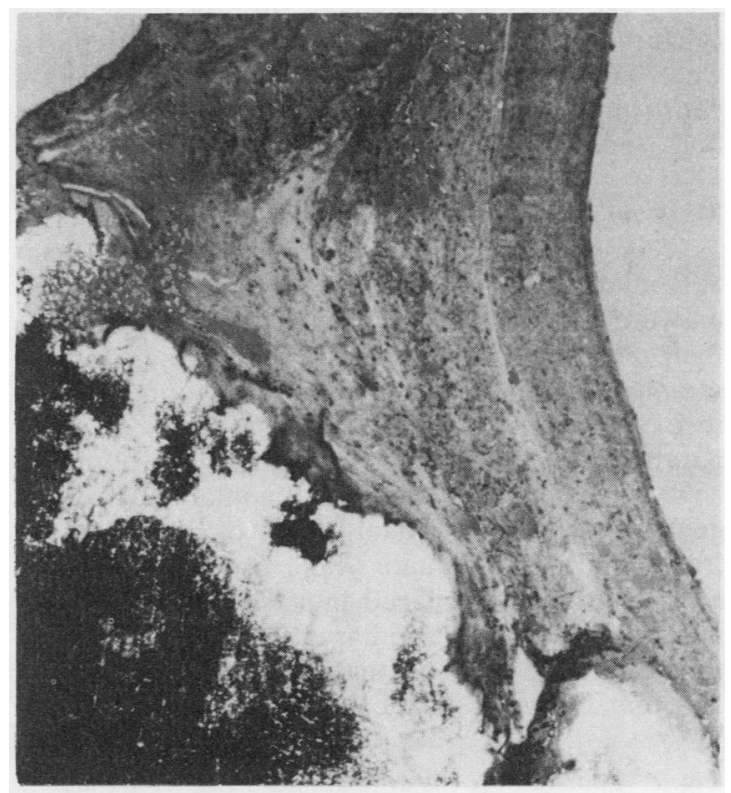

Fig. 1 Low power view of tophus at base of aortic valve. Birefringent urate crystals at periphery of tophus are bright with partially polarised light. Large mass of urate and calcium salts is not transilluminated and looks black. $\times 60$. (Haematoxylin and eosin.) 
vessel coronary disease and moderate left ventricular dysfunction. After catheterisation he developed intractable angina. He was then evaluated for possible myocardial infarction and underwent an operation for coronary artery bypass and replacement of an aortic valve. Biochemical findings on admission and preoperatively included serum uric acid concentrations of $0.773 \mathrm{mmol} / \mathrm{l}(13.1 \mathrm{mg} / 100 \mathrm{ml})$ and $0.474 \mathrm{mmol} / \mathrm{l}(7.9 \mathrm{mg} / 100 \mathrm{ml})$, respectively.

\section{MACROSCOPIC FINDINGS}

The resected aortic valve was received in alcoholic formalin $(10 \%)$. Four firm, partially calcified, grey-white fragments of tissue were recognisable as parts of thickened and deformed valve cusps. Reassembled, they measured $7.0 \times 1.0 \mathrm{~cm}$; their thickness varied from 0.1 to $0.2 \mathrm{~cm}$. One fragment contained a hard, slightly brittle, chalky white nodule measuring $0.3 \mathrm{~cm}$ in diameter.

\section{LIGHT MICROSCOPIC FINDINGS}

Sections of the nodule stained with haematoxylin and eosin and embedded in paraffin showed an acellular centre containing birefringent, needle shaped crystals visible on compensated polarised light microscopy (Fig. 1). Adjacent areas also showed massive deposits of partly amorphous and partly crystalline material; staining with von Kóssa and de Galantha stains was consistent with the presence of calcium and urates, respectively. These deposits were surrounded by a palisading cellular reaction consisting of histiocytes, a few giant cells of foreign body type, fibroblasts, and some lymphocytes.

\section{Material and methods}

Several calcified fragments fixed in alcoholic formalin were studied by X-ray diffraction to characterise their respective mineral compositions. Four of these samples had been dried in air after fixation; one was recovered from a block of tissue embedded in paraffin, which had been sectioned and found to have a chalky white nodule that contained birefringent needle shaped crystals. Each of the five tissue fragments was mounted whole on the end of an aluminium stub or placed intact in a fine $(0.7-1 \cdot 5$ $\mathrm{mm}$ diameter) glass capillary. The fragments were then examined by wide angle $\mathrm{X}$-ray diffraction in a $114 \mathrm{~mm}$ Debye-Scherrer powder camera (Philips).

Fig. 2 Patterns of $X$-ray diffraction patterns from calcified aortic valve $(a, c, e)$ and standards of hydroxyapatite $(b)$, whitlockite (d), and paraffin (f). Specimens dried in air (a and c) are characteristic of mixtures of hydroxyapatite or hydroxyapatite and whitlockite; birefringent specimen embedded in paraffin $(e)$ is sodium acid urate monohydrate. (See Table). Arrows show major reflections.
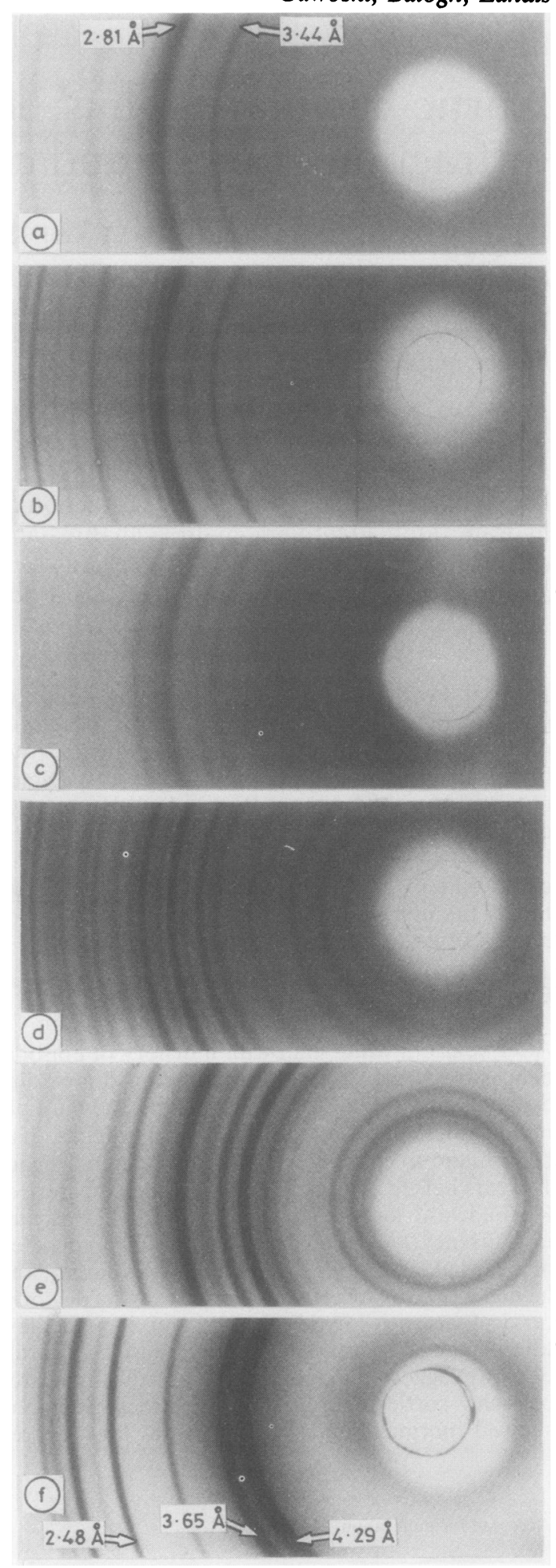
Interplanar lattice spacings $(\AA)$ and relative line intensities $\left(I / I_{\phi}\right)$ of aortic valve calcified fragments and standards ${ }^{4}$

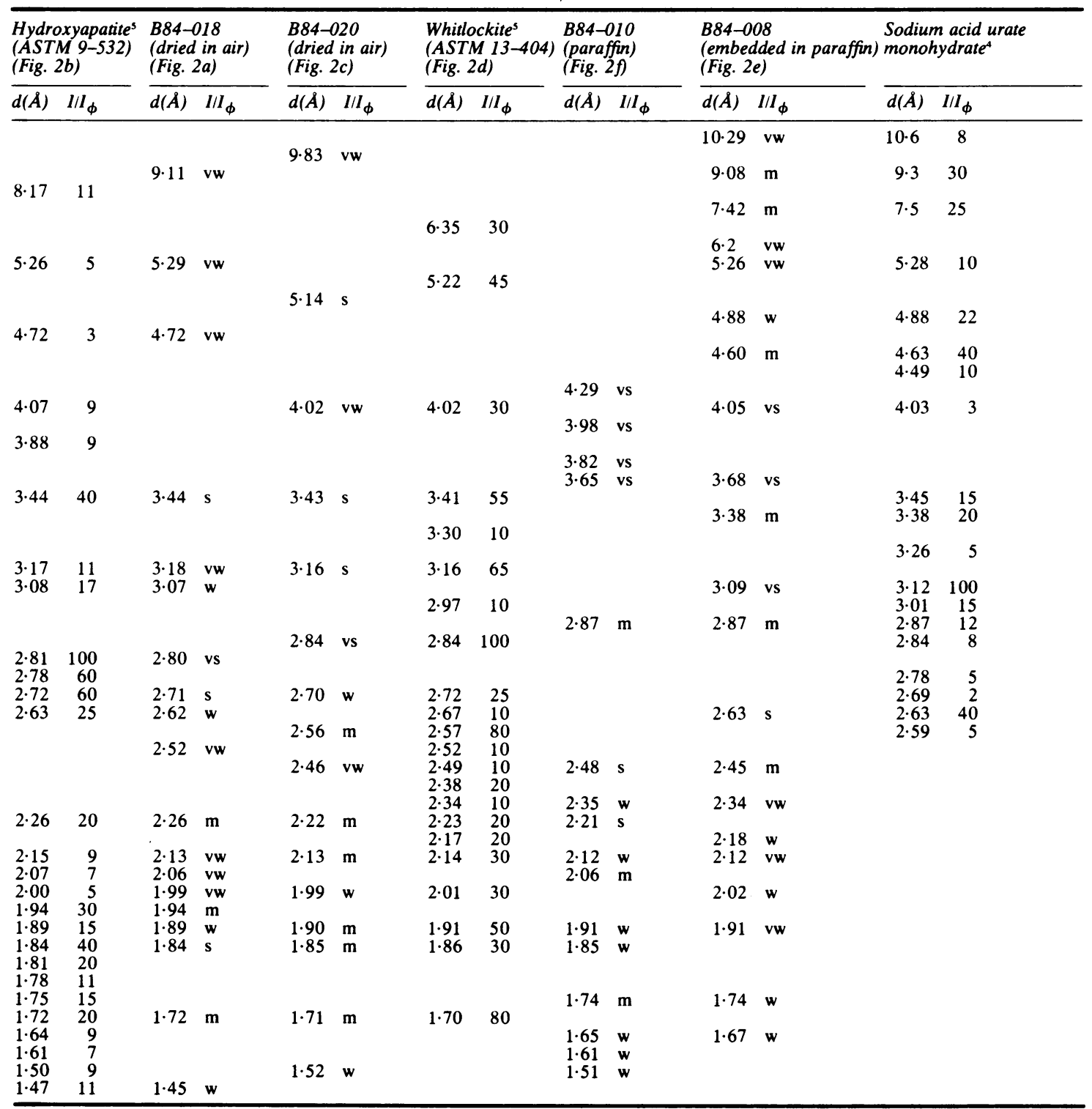

Line intensities of fragments are given as vw (very weak), w (weak), $\mathrm{m}$ (medium), s (strong), or vs (very strong). Calcified samples B84-018 and B84-020 were air-dried and B84-008 was paraffin embedded. B84-010 was paraffin alone.

Exposure times were eight to 12 hours, using nickel filtered $\mathrm{CuK} \alpha \alpha$ radiation $(\lambda=1.54 \AA)$ at $45 \mathrm{kV}$ and $30 \mathrm{~m} \AA$. Samples of paraffin wax alone and synthetically prepared calcium phosphate mineral phases were examined in the same manner and used as standards.

\section{Results}

Figure 2 shows the Debye-Scherrer diffraction patterns of two of the four samples dried in air (Figs. 2a and $2 c)$ and the single sample recovered from paraffin (Fig. 2e). Comparison of the patterns and 
identification of the interplanar lattice spacings (Table) show that the reflections of calcified fragments dried in air were those of poorly crystalline hydroxyapatite $\left(\mathrm{Ca}_{10}\left(\mathrm{PO}_{4}\right)_{6}(\mathrm{OH})_{2}\right)$ (Fig. 2a) or a mixture of hydroxyapatite and whitlockite $\left((\mathrm{Ca}, \mathrm{Mg})_{3}\left(\mathrm{PO}_{4}\right)_{2}\right)$ (Fig. $\left.2 \mathrm{c}\right)$; the other two specimens dried in air were similar. After the reflections of paraffin alone (Fig. 2f, Table) were accounted for the single sample known to have birefringent crystals on histological examination proved to contain sodium acid urate monohydrate $\left(\mathrm{C}_{5} \mathrm{H}_{3} \mathrm{~N}_{4} \mathrm{O}_{3} \mathrm{Na} \cdot \mathrm{H}_{2} \mathrm{O}\right)$ (Fig. 2e, Table). ${ }^{4}$

\section{Discussion}

Gouty tophi commonly occur in soft tissue, especially around cartilage, but are exceedingly rare in cardiac valves. Only nine cases have been reported: the tophi were found in the mitral valve in seven, in both the mitral and pulmonic valves in one, and in the aortic vale in one. ${ }^{16-13}$ Only two were surgical specimens, the mitral valves being affected in both. ${ }^{9^{13}}$

The present case was an incidental finding in a surgical specimen and was partly the result of an alcoholic fixative known to preserve urate salts in tissues. ${ }^{2}$ As clinical manifestations of gout in this patient had been sporadic and relatively mild valvular tophus had not been suspected. As with other cases, the tophus in this patient was associated with pronounced dystrophic calcification in the cardiac valve. Whether dystrophic calcification is a predisposing factor for or a sequel to the formation of gouty tophus is unclear. In the elderly both are fairly common. All reported cases of valvular gouty tophus, with one exception, have occurred in patients in their sixth to eighth decades.

An additional consideration in the context of mineral deposition in general is whether the calcium urate was itself formed in the tissue as an artefact. Under appropriate conditions in a local region of the valve the formation of urate could conceivably be strictly incidental to the formation of hydroxyapatite or whitlockite otherwise deposited. The precise mechanism in vivo of the formation of urate in this case cannot be clearly established from the evidence. Nevertheless, considering the long history of renal stones containing uric acid and calcium in this patient, it is not surprising that a deposit of calcium urate formed outside the kidney.

The method of preparing tissue in alcoholic formalin used in this study helps to maintain the integrity of urate during processing for analysis. ${ }^{2}$ Aqueous fixation is a poor treatment for other mineral phases such as certain calcium phosphates in calcified tissues. ${ }^{3}$ For any surgical sample it is critical for the definitive identification of its mineral composition (and many components of organic tissue as well) that the exposure of the specimen to chemical fixatives be minimised or eliminated completely. Optimally, the samples should be immediately and rapidly frozen on dissection and then analysed in a frozen and hydrated state, or, alternatively but somewhat less ideally, they may be lyophilised (freeze dried) or dried in air.

At least three distinct mineral phases were identified in the cardiac tissue of this patient. Hydroxyapatite is a common calcium phosphate found in normal vertebrate calcified tissues as well as in various pathological conditions. ${ }^{14}$ Whitlockite, composed in part of calcium or magnesium, or both, and sodium acid urate monohydrate have been identified less often; and sodium acid urate monohydrate was first definitively reported here in an aortic valve. The importance of these different mineral phases in the soft tissues and the specific regions of the valve is not clear.

\section{References}

' Coupland S. Gouty concretions on the aortic valves. Transactions of the Pathological Society of London 1872-3;24:69-72.

${ }^{2}$ Lillie RD. Histopathological technic and practical histochemistry. 3rd ed. New York: McGraw-Hill, 1965.

${ }^{3}$ Landis WJ, Glimcher MJ. Electron diffraction and electron probe microanalysis of the mineral phase in bone tissue prepared by anhydrous techniques. J Ultrastruct Res 1978; 63: 188-223.

4 Sutor DJ, Scheidt S. Identification standards for human urinary calculus components, using crystallographic methods. $\mathrm{Br} J$ Urol 1968;40:22-8.

5 Joint Committee on Powder Diffraction Standards of the American Society for Testing and Materials, Mineral powder diffraction file, data book. Swarthmore, Pennsylvania: International Centre for Diffraction Data, 1980.

- Bunim JJ, McEwen C. Tophus of the mitral valve in gout. Archives of Pathology 1940;29:700-4.

' Chung EB. Histologic changes in gout. Georgetown Medical Bulletin 1962;15:269-75.

${ }^{8}$ Curtiss EI, Miller TR, Shapiro LS. Pulmonic regurgitation due to valvular tophi. Circulation 1983;67:699-701.

"Dennstedt FE, Weilbaecher DG. Tophaceous mitral valve: report of a case. Am J Surg Pathol 1982;6:79-81.

${ }^{10}$ Lancereau E. Diathèse urique dans un cas de néphrite interstitielle chronique. Gazette Médicale de Paris (3rd series) 1868;23:187-8.

" Pund EE, Hawley RL, McGee HJ, Blount SG. Gouty heart. New Engl J Med 1960;263:835-8.

12 Traut EF, Knight AA, Szanto PB, Passerelli EW. Specific vascular changes in gout. JAMA 1954;156:591-3.

${ }^{13}$ Scalapino JN, Edwards WD, Steckelberg JM, Wooten RS, Callahan JA, Ginsburg WW. Mitral stenosis associated with valvular tophi. Mayo Clin Proc 1984;59:509-12.

${ }^{14} \mathrm{Kim} \mathrm{KM}$, Trump BF. Amorphous calcium precipitations in human aortic valve. Calcified Tissue Research 1975;18:15560.

Requests for reprints to: Dr K Balogh, Department of Pathology, New England Deaconess Hospital, 185 Pilgrim Road, Boston, Massachusetts 02215, United States. 